\title{
Natural Antibody to a Human Bladder Carcinoma Cell Line
}

\author{
H. Barton Grossman \\ University of Michigan Medical Center, Department of Surgery, Section of Urology, Ann Arbor, MI 48109, USA
}

\begin{abstract}
Summary. Sera from 144 healthy blood donors were screened for the presence of antibody against the bladder carcinoma cell line RT4 by means of an immune adherence assay. Only one serum (9241) demonstrated high activity with a titer of 1/124. Qualitative and quantitative absorption analyses were carried out with a wide variety of cells to characterize the specificity of the reaction. Cells used for absorption were both cultured and non-cultured and normal and malignant. The reactivity was absorbed by the bladder cancer cell lines RT4 and 5637 and the lung cancer cell line $S K-L C-L L$. In addition, surgically obtained urothelium from a patient with transitional cell carcinoma abrogated reactivity. No other absorbing cells removed the reactivity of serum 9241 for $R T 4$. The antigen defined by this serologic reaction is heat-stable and trypsinresistant, as demonstrated by using heated or trypsinized RTA cells for absorption.

This study shows that naturally occurring antibody directed toward cell surface antigens of tumor cells is present in some normal individuals. This finding is important in the evaluation of a possible causal relationship between the presence of antibody specific for tumor cell antigens and the development of neoplasia.
\end{abstract}

\section{Introduction}

Autologous serologic typing of human tumor antigens has been applied to the study of cell surface antigens of malignant melanoma [1, 10, 11], acute leukemia [4], astrocytoma [9], and renal carcinoma [14]. Autologous typing is a method that uses autologous combinations of serum and target cells to eliminate alloantigens as a source of positive reactions. The characterization of these antigens by absorption analysis has resulted in the definition of three classes according to the specificity of the system being studied. Class 1 antigens are limited to autologous tumor cells and cannot be detected by absorption on any other normal or malignant cells. Class 2 antigens are found on autologous as well as certain allogeneic tumors, but not on normal cells. Class 3 antigens are detected on a wide variety of normal and malignant cells of both human and animal origin.

Autologous typing has clearly demonstrated serological reactivity to surface antigens on cultured tumor cells by patients with several different tumors. The existence of antibody specific for tumor-cell-restricted antigens raises the question as to whether the presence of antibody is causally related to neoplasia. In order to understand the relationship of antibody to the presence of tumor, a normal population needs to be surveyed to determine whether specific naturally occurring antibody directed toward cell surface antigens of tumor cells is present in normal individuals. In such a study performed on melanoma target cells, 6 of 106 normal males had antibody to a class 2 melanoma surface antigen [6]. To determine whether this occurs with other neoplasms, natural antibody was searched for against the bladder carcinoma cell line RT4.

\section{Materials and Methods}

Tissue Culture. All cell cultures except for lymphoid lines were maintained with Eagle's MEM supplemented with 1\% non-essential amino acids, $2 \mathrm{mM}$ glutamine, 100 units penicillin/ml, $100 \mu \mathrm{g}$ streptomycin $/ \mathrm{ml}$, and $10 \%$ fetal bovine serum (FBS). Epstein-Barr virus (EBV)-transformed lymphoblast and Raji cell lines were maintained in RPMI 1640 with $2 \mathrm{~m} M$ glutamine, $1 \%$ non-essential amino acids, penicillin 100 units $/ \mathrm{ml}$, streptomycin $100 \mu \mathrm{g} / \mathrm{ml}$, and $10 \%$ FBS. In order to remove heterologous FBS components, RT4 cells were cultured in $10 \%$ human A positive serum for at least five passages.

Cells in tissue culture were fed with medium two or three times weekly, depending on growth characteristics and the size of the tissue culture flask. The cell lines were subcultured at intervals ranging from once a week to once a month. Cultures were repeatedly checked for contamination with mycoplasma, fungi, and bacteria. Contaminated cultures were discarded.

SK-GR-1 was derived from a thoracic metastasis of a patient with embryonal carcinoma. The bladder carcinomas RT4, SCaBER, SW-800, 5637, and 253J; the lung carcinomas Calu-1 and Calu-3; and the malignant teratoma Tera-1 were supplied by Dr J. Fogh, Sloan-Kettering Institute. The derivations of other cell lines have been noted elsewhere $[1,3,4,6$, $9-11,14]$.

Sera. Sera were collected from healthy blood donors and stored at $-70^{\circ} \mathrm{C}$. Serum 9241 was obtained from a healthy non-transfused 34-year-old Caucasian male. Anti-A and anti-B sera were obtained from Hyland, Division of Travenol Laboratories, Inc., Costa Mesa, CA, USA.

Serological Procedures. The immune adherence assay (IA) was performed as previously described and modified for Falcon 3034 plates (Falcon Labware, Division of Becton, Dickinson \& Co., Oxnard, CA, USA $[10,14]$.

In brief, target cells were trypsinized, washed, and seeded into Falcon 3034 plates at a density of 200 cells/well $(0.01 \mathrm{ml})$. 
Plates were incubated at $37^{\circ} \mathrm{C}$ with humidified $5 \% \mathrm{CO}_{2}$ and used 2-4 days thereafter. Sera were diluted in Veronal buffer medium (VBM) with 5\% FBS (VBM-FBS). The wells were washed three times with VBM-FBS and once with VBM, after which $0.01 \mathrm{ml}$ of diluted serum was added per well. The plates were incubated at $4^{\circ} \mathrm{C}$ for $1 \mathrm{~h}$ and again washed. Indicator cells ( $0.5 \%$ human 0 erythrocytes and guinea pig serum as a source of complement diluted 1/80 in VBM) were added in $0.01 \mathrm{ml}$ aliquots to each well. The plates were incubated at $37^{\circ} \mathrm{C}$ with humidified $5 \% \mathrm{CO}_{2}$ for $30 \mathrm{~min}$. After incubation, the plates were gently washed once with VBM-FBS and evaluated under a light microscope. In later experiments (PBS-ALB) phosphate-buffered saline with $0.2 \%$ albumin (Miles Laboratories, Inc., Elkhart, IN 46515, USA) was substituted for VBM and VBM-FBS. An individual target cell was scored as positive when $50 \%$ or more of its perimeter was surrounded by indicator cells. When test cells grown in medium containing human serum were used, assays were done with either dextrose-gelatin-veronal buffer (DGV) or PBS-ALB used as the diluent and washing agent, with identical results.

Qualitative absorption tests were performed by absorbing $30 \mu \mathrm{l}$ serum ( $25 \mu \mathrm{l}$ for quantitative absorptions) diluted according to the end-point with $20 \mu \mathrm{l}\left(8 \times 10^{4}\right.$ to $2 \times 10^{7}$ cells for quantitative absorptions) of washed packed cells for $1 \mathrm{~h}$ at $4^{\circ} \mathrm{C}$ and testing for residual antibody on target cells grown in Falcon 3034 plates. Heat stability of antigen was determined by heating cells for $5 \mathrm{~min}$ at $100^{\circ} \mathrm{C}$ and then performing qualitative absorption. All absorption tests were performed on at least two separate days except for normal kidney cells EQ, FJ, FR, FS, and skin fibroblast cells DY, EP, FL, FS.

Fresh human urothelium was used for absorptions in four instances. These specimens were removed for medically indicated reasons and a portion was used for this study. The specimens were aseptically transferred to the laboratory and kept in phosphate-buffered saline with penicillin 100 units $/ \mathrm{ml}$ and streptomycin $100 \mu \mathrm{g} / \mathrm{ml}$ at $4^{\circ} \mathrm{C}$ until use (approximately $24 \mathrm{~h}$ later). At the time of absorption, the urothelial surface was gently scraped off with a scalpel and the cells were then washed and packed for qualitative absorption. Because of the limited numbers of cells available, each of these absorptions could be performed only once.

\section{Results}

\section{Reactions of Normal Human Sera with RT4}

Sera from 144 healthy blood donors were screened at dilutions of $1 / 4,1 / 16$, and $1 / 64$ against RT4 bladder carcinoma cells with the IA assay. One hundred twenty-four had no titer (less than $50 \%$ reactivity at $1 / 4$ dilution), eighteen had a titer of $1 / 4$, and one had a titer of $1 / 16$. Only one serum (9241) exhibited significant reactivity with a titer of $1 / 124$ on subsequent testing. Blood group A and B antigens do not account for these results. RT4 was derived from a blood group 0 male and does not express blood group A or B antigens as determined by IA assays with anti-A and anti-B sera against RT4 target cells. Serum 9241 was obtained from a healthy, non-transfused 34-year-old Caucasian male who is blood type 0 positive. Samples of serum collected over a 6-month period exhibited similar reactivity.

\section{Qualitative Absorption Analysis of 9241}

Figure 1 illustrates an individual absorption and Table 1 summarizes the results of the analysis. The bladder cancer lines

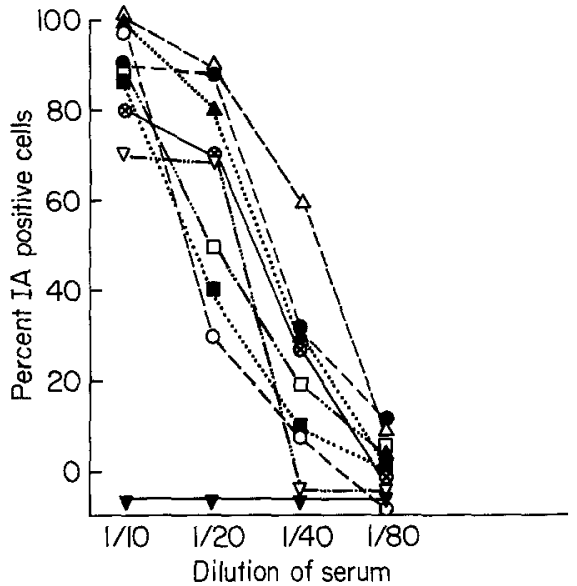

Fig. 1. Qualitative absorption analysis of serum 9241 for bladder cancer RT4. RT4 completely removed reactivity of serum 9241 . Sheep erythrocytes (SRBC), DY skin fibroblasts, EQ normal kidney, renal cancers Caki-1 and SK-RC-16, and melanomas SK-MEL-37 and MeWo did not remove reactivity. $(\triangle---\triangle)$ Unabsorbed serum; $(\bullet---\bullet)$ SRBC; $(\boldsymbol{\Delta} \cdots \cdot \boldsymbol{\Delta})$ DY skin fibroblasts; $(\mathrm{O}---0) \mathrm{EQ}$

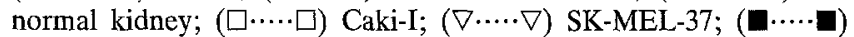
SK-RC-16; $(\otimes---\otimes)$ MeWo; $(\nabla---\nabla)$ RT4

Table 1. Summary of IA absorbtion of serum 9241 for RT4

\begin{tabular}{|c|c|c|}
\hline Complete absorption & No absorption & \\
\hline $\begin{array}{l}\text { Bladder cancer } \\
\text { RT4 } \\
\text { RT4 (heated) } \\
\text { RT4 (human serum) } \\
\text { RT4 (trypsinized) } \\
5637\end{array}$ & $\begin{array}{l}\text { Bladder cancer } \\
\text { J82 } \\
\text { SCaBER } \\
\text { SW-800 } \\
\text { T24 } \\
\text { 253J }\end{array}$ & $\begin{array}{l}\text { Testicular cancer } \\
\text { SK-GR-1 } \\
\text { Tera-1 }\end{array}$ \\
\hline \multirow[t]{17}{*}{$\begin{array}{l}\text { Lung cancer } \\
\text { SK-LC-LL }\end{array}$} & $\begin{array}{l}\text { Cervical cancer } \\
\text { ME-180 }\end{array}$ & $\begin{array}{l}\text { Burkitt Iymphoma } \\
\text { Raji }\end{array}$ \\
\hline & $\begin{array}{l}\text { Colon cancer } \\
\text { HT- } 29\end{array}$ & $\begin{array}{l}\text { EBV-transformed } \\
\text { lymphoblasts } \\
\mathrm{AG} \\
\mathrm{AX}\end{array}$ \\
\hline & Glioma & $\mathrm{BE}$ \\
\hline & & DW \\
\hline & $178 \mathrm{MG}$ & $\begin{array}{l}\text { Normal kidney } \\
\text { EQ }\end{array}$ \\
\hline & Lung cancer & FJ \\
\hline & Calu-1 & FP \\
\hline & Calu-3 & $\begin{array}{l}\text { FR } \\
\text { FS }\end{array}$ \\
\hline & $\begin{array}{l}\text { Melanoma } \\
\text { MeWo }\end{array}$ & GR \\
\hline & SK-MEL-28 & Skin fibroblasts \\
\hline & SK-MEL-37 & $\begin{array}{l}\text { DY } \\
\text { EP }\end{array}$ \\
\hline & Renal Cancer & FJ \\
\hline & Caki-1 & FL \\
\hline & $\begin{array}{l}\text { SK-RC-2 } \\
\text { SK-RC-6 }\end{array}$ & $\mathrm{FS}$ \\
\hline & SK-RC-8 & Monkey kidney \\
\hline & SK-RC-16 & Vero \\
\hline & & $\begin{array}{l}\text { Noncultured cells } \\
0 \text { erythrocytes } \\
\text { A erythrocytes } \\
\text { B erythrocytes } \\
\text { AB erythrocytes } \\
\text { Sheep erythrocytes }\end{array}$ \\
\hline
\end{tabular}


Table 2. Summary of absorptions with human urothelium

\begin{tabular}{|c|c|c|c|c|c|c|c|c|}
\hline $\begin{array}{l}\text { Speci- } \\
\text { men }\end{array}$ & Age & Sex & Race & $\begin{array}{l}\text { Blood } \\
\text { type }\end{array}$ & Operation & Pathologic diagnosis & $\begin{array}{l}\text { Tissue for } \\
\text { absorption }\end{array}$ & $\begin{array}{l}\text { Absorption } \\
\text { with } 9241\end{array}$ \\
\hline 1 & 45 & $\mathrm{~F}$ & $\mathrm{C}$ & B pos. & Pyeloplasty & $\begin{array}{l}\text { Fibrosis of lamina } \\
\text { propria }\end{array}$ & Renal pelvis & Negative \\
\hline 2 & 51 & M & $\mathrm{C}$ & AB pos. & Radical nephrectomy & Renal carcinoma & Ureter & Negative \\
\hline 3 & 56 & $\mathrm{M}$ & $\mathrm{C}$ & 0 pos. & Nephroureterectomy & $\begin{array}{l}\text { Grade I transitional } \\
\text { cell carcinoma }\end{array}$ & $\begin{array}{l}\text { Renal pelvis } \\
\text { and ureter }\end{array}$ & Complete \\
\hline 4 & 7 & M & $\mathrm{C}$ & 0 neg. & Pyeloplasty & $\begin{array}{l}\text { Urothelium covering } \\
\text { fibrous connective } \\
\text { tissue }\end{array}$ & Renal pelvis & Negative \\
\hline
\end{tabular}

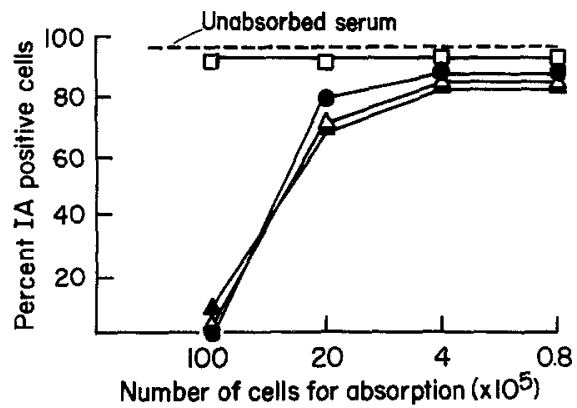

Fig. 2. Quantitative absorption analysis of serum 9241 for bladder carcinoma RT4. Aliquots of $1 / 3$ diluted serum were absorbed with counted numbers of RT4, 253J, 5637, and SK-LC-LL cells and then tested for residual IA activity for RT4 cells. The bladder cancers RT4 and 5637 and the lung cancer SK-LC-LL completely removed reactivity. There was no absorption by the bladder carcinoma $253 \mathrm{~J}$.

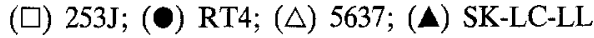

RT4 and 5637 and the lung cancer line SK-LC-LL were the only cell lines which absorbed reactivity. Other bladder carcinoma cell lines and other malignant cell lines did not abrogate reactivity. Similarly, cultured normal kidney cells, fibroblasts, fetal cells, xenogenic cells, and red blood cells did not remove activity. To further rule out alloantigens of the HLA complex, lymphoblast cell lines transformed with EBV were used for absorption and yielded negative results. Antigens related to FBS were eliminated because RT4 cells grown in human A positive serum for five passages completely absorbed the antibody. Absorption analysis demonstrated the heat-stability and trypsin-resistant nature of the antigen. There was equal absorption with RT4 whether harvested by scraping or trypsinization. In addition, RT4 continued to absorb reactivity after heating to $100^{\circ} \mathrm{C}$ for $5 \mathrm{~min}$.

\section{Quantitative Absorption Analysis of 9241}

To further evaluate the qualitative absorptions by RT4, 5637, and SK-LC-LL, quantitative absorptions were performed as illustrated in Fig. 2. These demonstrate identical absorption patterns and suggest that these cell lines present an equal amount of the antigen(s) per cell as defined by serum 9241 .

\section{Qualitative Absorptions with Human Urothelium}

Four absorptions were performed with normal urothelium from surgical specimens. Clinical data and absorption results are shown in Table 2. Specimens 1,2, and 4 were from patients who had no history of transitional cell carcinoma. None of these specimens abrogated reactivity in a qualitative absorption analysis. Specimen 3 was taken from a nephroureterectomy specimen containing several areas of grade I transitional cell carcinoma. Grossly and histologically normal urothelium from the ureter and renal pelvis completely absorbed reactivity by 9241 .

\section{Discussion}

The first report af a specific naturally occurring antibody to tumor cell surface antigens in a healthy human was published in 1980 [6]. Houghton and co-workers demonstrated the existence of natural antibody to a class 2 (tumor shared) antigen on a cultured melanoma cell line with an anti-C3 mixed hemadsorption assay. When the IA assay was used on three different melanoma targets the proportion of positive reactions for sera with a titer of at least $1 / 8$ ranged from $5.6 \%$ to $15.1 \%$. The prevalence of sera with a similar degree of reactivity to RT4 in my study was only $1.3 \%$.

RT4 was derived from a blood type 0 male (J. Fogh, personal communication) and does not express blood group A or $B$ antigens in tissue culture. Absorptions with human $A$ and $B$ erythrocytes confirmed that the ovserved reactions were not blood group-related. The complete absorption of activity by RT4 grown in human serum for more than five passages is good evidence that FBS alloantigens are not the source of the positive reactions. Alloantibodies to HLA products cannot be completely eliminated because of the lack of autologous normal cells for absorption, but are unlikely because the serum was derived from a non-transfused male and because of the extensive negative absorptions including EBV-transformed lymphoblast cell lines. Serum 9241 defines a class 2 antigen that is shared by one other bladder carcinoma and a lung carcinoma. The antigen is both heat- and trypsin-stable, suggesting that it may not be a protein. It may be chemically more similar to the class 2 melanoma antigen $\mathrm{AH}$, which is a glycolipid [8], as opposed to the prototype class 1 melanoma antigen $\mathrm{AU}$, which is a glycoprotein [2].

Absorptions with surgically obtained human urothelium from three patients with benign urologic diseases did not abrogate reactivity. The sole absorption from a patient with transitional cell carcinoma removed reactivity even though the urothelium was from grossly and histologically normal areas. There are several possible explanations for this. The first is that the patient with transitional cell carcinoma shares a highly restricted HLA antigen with RT4. This is unlikely for the reasons discussed above, but remains a consideration whenever one is dealing with allogeneic analysis. The second is that unrecognized areas of tumor cells were present in the tissue 
used for absorption and that the antibody is directed at an antigen restricted to tumor cells. The third is that some tumor cells manifest this antigen early in the development of the carcinogenic phenotype prior to the development of changes visible by conventional light microscopy. The separation of these latter two possibilities is not possible at this point in the analysis, and, in fact, both are possible. Transitional cell carcinoma is known to be a field change disease [12] in at least some cases, and early changes prior to gross neoplasia have been documented [13].

The significance of natural antibody is unclear. The discovery of this phenomenon is somewhat similar to the finding of natural killer (NK) cells in cell-mediated immunity $[5,7]$. Whether or not these phenomena play any role in immunologic surveillance is purely speculative at this point. Further screening of different populations and tumor types and follow-up of the individuals studied may yield some clues to this problem.

Acknowledgments. The work reported in this paper was supported in part by the Ferdinand C. Valentine Fellowship of the Section of Urology, New York Academy of Medicine, and by the Institutional Research Grant no. IN-40U to the University of Michigan from the American Cancer Society.

\section{References}

1. Carey TE, Takahashi T, Resnick LA, Oettgen HF, OId LJ (1976) Cell surface antigens of human malignant melanoma. I. Mixed hemadsorption assays for humoral immunity to cultured autologous melanoma cells. Proc Natl Acad Sci USA 73: 3279

2. Carey TE, Lloyd KO, Takahashi T, Travassos LR, Old LJ (1979) AU cell-surface antigen of human malignant melanoma: Solubilization and partial characterization. Proc Natl Acad Sci USA $76: 2898$

3. Fogh J, Trempe G (1975) Human tumor cells in vitro. Plenum Press, New York, p 115

4. Garrett TJ, Takahashi T, Clarkson BD, Old LJ (1977) Detection of antibody to autologous human leukemia cells by immune adherence assay. Proc Natl Acad Sci USA 74:4587
5. Herberman RB, Nunn ME, Lavrin DH, Asofsky R (1973) Effect of antibody to $\theta$ antigen on cell-mediated immunity induced in syngeneic mice by murine sarcoma virus. J Natl Cancer Inst 51: 1509

6. Houghton AN, Taormina MC, Ikeda $H$, Watanabe $T$, Oettgen HF, Old LJ (1980) Serological survey of normal humans for natural antibody to cell surface antigens of melanoma. Proc Natl Acad Sci USA 77: 4260

7. McCoy JL, Herberman RB, Rosenberg EB, Donnelly FC, Levine $\mathrm{PH}$, Alford C (1973) ${ }^{51}$ Chromium-release assay for cell-mediated cytotoxicity of human leukemia and lymphoid tissue-culture cells. Natl Cancer Inst Monogr 37:59

8. Old LJ (1981) Cancer immunology: The search for specificity G.H.A. Clowes memorial lecture. Cancer Res 41:361

9. Pfreundschuh M, Shiku H, Takahashi T, Ueda R, Ransohoff J, Oettgen HF, Old LJ (1978) Serological analysis of cell surface antigens of malignant brain tumors. Proc Natl Acad Sci USA $75: 5122$

10. Shiku H, Takahashi T, Oettgen HF, Old LJ (1976) Cell surface antigens of human malignant melanoma. II. Serological typing with immune adherence assays and definition of two new surface antigens. J Exp Med 144: 873

11. Shiku H, Takahashi T, Resnick LA, Oettgen HF, Old LJ (1977) Cell surface antigens of human malignant melanoma. III. Recognition of autoantibodies with unusual characteristics. J Exp Med 145: 784

12. Soloway MS, Murphy W, Rao MK, Cox C (1978) Serial multiple-site biopsies in patients with bladder cancer. J Urol $120: 57$

13. Stein BS, Reyes JM, Petersen RO, McNellis D, Kendall AR (1981) Specific red cell adherence: Immunologic evaluation of random mucosal biopsies in carcinoma of the bladder. $J$ Urol $126: 37$

14. Ueda R, Shiku H, Pfreundschuh M, Takahashi T, Li LTC, Whitmore WF, Oettgen HF, Old LJ (1979) Cell surface antigens of human renal cancer defined by autologous typing. J Exp Med $150: 564$

Accepted February 9, 1981/Accepted March 23, 1982 